\title{
51
}

\section{Updating train-the-trainer activities: an action research study}

Christian Bessiere

CNRS/IRPEACS Research Institute

Ecully

France

Roger Guir

CNAM/ARDEMI

Ecully

France

\begin{abstract}
Considerable use of information technologies for educational and training purposes modifies the activities of the actors involved. Within the framework of an action training project involving education and training professionals from training organizations and large companies a study has been conducted to identify new or changed roles and competencies in the training function so as to update train-the-trainer activities. This paper presents the framework, methodology and results of this action research study.
\end{abstract}

Main conference themes: information technology, teacher education

Educational areas:

Study topics:

Secondary keywords: interactive, multimedia, research 


\section{INTRODUCTION}

The explosion of applications of Information Technology in society and their advancement into education and training affect the learning process itself. While still at a pioneering stage the social and pedagogical aspects now limit the drive towards more efficient uses of IT. An entire set of expressions (self, flexible, resource based, distant, open, collaborative, etc.) combined with the word 'learning' expresses the diversity. Use of IT affects the activities of all actors involved and thus their competencies as well. Trainers and trainees will both have to develop new skills. Learners will have to be competent in learning: "The more person-tailored and the more individualised offers for learning and qualification become, the more they need to balance the additional chances they offer with a much more demanding qualification of the learner" [1]. Teachers will have to deal with this challenge by designing, producing and pilot learning activities aimed at increasingly learner centred and technology supported learning situations. The ultimate aim is to achieve train-the-trainer level for which identification of the new and transformed trainer competencies of appear to be a prerequisite. And it is this prerequisite which is the focus of this paper.

\section{An action research framework}

ARDEMI (Association for the Research and Development of Interactive Multimedia for Training and Education, Region Rhône-Alpes, France) was founded in 1984 and acts as a club for institutions which produce and use IT for educational and training purposes. The aim of ARDEMI is to develop multimedia courseware in partnership according to its members' common requirements. ARDEMI's members have recently extended their cooperation to the utilization of this courseware.

Social, organizational and teaching issues should balance current technological efforts. From their own experience most institutions claim that existing train-the-trainer tools do not fulfil their requirements. The initial request therefore was for improved information on existing courses and for design and organization of specific train-the-trainer modules.

As a first step a working group analyzed this common objective and found that real needs were specific to each institution and closely related with the ongoing educational changes.

On the basis of these findings an action training project aimed at both analysis and involvement was implemented for a period of six months from November 1993 to April 1994. Participants were trainers or training heads of training organizations and training departments of major companies (see Table 1). 
Their individual experiences as trainers were synthesized and compared to experiences of other institutions represented by:

- Mrs Orofiamma: Change in multimedia training systems, the new positions and roles of the actors, CNAM (Paris);

- Mr Dupuis: Resource centres and distance teaching, CNAM (Paris).

- Mrs Chrétien-Petiot: Resource centres, IFACE (Paris).

- Mrs Bourdeau: The hyperguide: a tool for trainers, Télé Université du Québec, Montréal, Canada.

Table 1

\begin{tabular}{|c|c|c|c|c|c|}
\hline $\begin{array}{l}\text { New jobs in relation with new } \\
\text { technologies in training }\end{array}$ & $\begin{array}{l}\text { Head } \\
\text { Resource } \\
\text { Centre } \\
\end{array}$ & $\begin{array}{c}\text { Head } \\
\text { Multimedia } \\
\text { Open Learning }\end{array}$ & Trainer & Tutor & $\begin{array}{l}\text { Animator } \\
\text { or } \\
\text { Monitor }\end{array}$ \\
\hline $\begin{array}{l}\text { INDUSTRIES(training departments) } \\
\text { LAFARGE (Cements) } \\
\text { LYONNAISE DE BANQUE } \\
\text { RENAULT VI (Trucks and buses) } \\
\text { S.N.C.F. (French Railways) } \\
\end{array}$ & $\begin{array}{l}\mathrm{X} \\
\mathrm{X} \\
\mathrm{X} \\
\end{array}$ & $X$ & $\begin{array}{l}\mathrm{X} \\
\mathrm{X} \\
\mathrm{X} \\
\mathrm{X}\end{array}$ & $\begin{array}{l}\mathrm{X} \\
\mathrm{X} \\
\end{array}$ & $\begin{array}{l}X \\
X \\
X \\
\end{array}$ \\
\hline $\begin{array}{l}\text { TRAINING ORGANIZATIONS } \\
\text { AFPA / CPTA (National Association for Adult } \\
\text { Vocational Training, Centre for Trainer } \\
\text { Training) }\end{array}$ & $\mathrm{X}$ & & $X$ & & \\
\hline $\begin{array}{l}\text { CHU (Hospital, Nursing School and Training } \\
\text { Centre) }\end{array}$ & $\mathrm{X}$ & & $\mathrm{X}$ & $X$ & \\
\hline $\begin{array}{l}\text { CREF / Education Nationale (Ministry of } \\
\text { National Education, Continuing Education } \\
\text { Resource Centre) }\end{array}$ & $\mathrm{X}$ & $X$ & $X$ & & $\mathrm{X}$ \\
\hline $\begin{array}{l}\text { GRETA Langue / Education Nationale } \\
\text { (Ministry of National Education, Continuing } \\
\text { Education School, Language training) } \\
\text { LADAPT (Training Centre for Handicapped } \\
\text { People) }\end{array}$ & $\mathrm{X}$ & $X$ & $X$ & & $X$ \\
\hline
\end{tabular}

The action training combined many aspects of diverse level and nature, though all related to the question of which competencies the different training actors should have and how these were related to the new technology. Analysis showed that there was a strong trend towards the individualization of training in organizational, pedagogical or relational aspects. The role of the new technology was clarified as it was no longer seen as the cause of changes, but as playing a dual role in revealing and bringing about changes. Clearer understanding resulted in that changes observed do not just stem from addition of technological competencies.

The analytical study of the roles and competencies of the actors in the training, initially planned for the first phase only, was extended throughout the project. It 
was progressively transformed into an action research aimed at identifying the nature of the changes affecting the roles and competencies of the trainers.

\section{METHODOLOGICAL FRAMEWORK OF THE ACTION RESEARCH STUDY}

The action research study was carried out in two stages: the first was action training which produced the concepts and analytical tools relevant to the second stage, the field study.

Table 2

\begin{tabular}{|c|c|c|c|c|c|}
\hline $\begin{array}{l}\text { Major functions or roles } \\
\text { (the functions do not describe jobs, } \\
\text { individual jobs comprise } \\
\text { several roles) }\end{array}$ & $\begin{array}{l}\text { Head } \\
\text { Resource } \\
\text { Centre }\end{array}$ & $\begin{array}{l}\text { Head Multi- } \\
\text { media } \\
\text { Open } \\
\text { Learning }\end{array}$ & Trainer & Tutor & $\begin{array}{l}\text { Animator } \\
\text { or } \\
\text { Monitor }\end{array}$ \\
\hline $\begin{array}{l}1 \text { - Individual development and guidance } \\
\text { counsellor } \\
2 \text { - Needs and tasks analyst } \\
3 \text { - Training program designer } \\
4 \text { - Designer of individualized curriculum } \\
5 \text { - Designer of instructional materials } \\
6 \text { - Multimedia specialist } \\
7 \text { - Instructor } \\
8 \text { - Animator and group facilitator } \\
9 \text { - Evaluator } \\
\text { (10 - Transfer agent) } \\
11 \text { - Program and facilities administrator } \\
12 \text { - Manager } \\
13 \text { - Strategist } \\
14 \text { - Overall training systems designer }\end{array}$ & $\begin{array}{l}X \\
X \\
X \\
X\end{array}$ & $\begin{array}{l}X \\
X \\
X\end{array}$ & $\begin{array}{l}X \\
X \\
X \\
X \\
X \\
X \\
X\end{array}$ & $\begin{array}{l}X \\
X \\
X \\
X\end{array}$ & $\begin{array}{l}X \\
X \\
X\end{array}$ \\
\hline
\end{tabular}

\section{Establishment and validation of the frame of reference.}

A description of the initial situation in terms of a frame of reference was needed. Because of the diversity of institutions participating establishing agreement and common understanding of a professional frame of reference accepted by all participants was essential. The frame of reference adopted is based on two already existing ones: the first comes from one of the institutions participating in the training [2], while the other originates from America [3] selected since it takes professional development into account. 
Table 3

\begin{tabular}{|c|c|c|c|c|c|}
\hline Key competencies & $\begin{array}{c}\text { Head } \\
\text { Resource } \\
\text { Centre } \\
\end{array}$ & $\begin{array}{l}\text { Head Multi- } \\
\text { media Open } \\
\text { Learning } \\
\end{array}$ & Trainer & Tutor & $\begin{array}{l}\text { Animator } \\
\text { or Monitor }\end{array}$ \\
\hline $\begin{array}{l}\text { I. ORGANIZATION and } \\
\text { ADMINISTRATION } \\
\text { 1- delegation skill } \\
\text { 2- facilities and logistics skill }\end{array}$ & $\begin{array}{l}X \\
X \\
\end{array}$ & $\begin{array}{l}X \\
X \\
\end{array}$ & & & $\mathrm{X}$ \\
\hline $\begin{array}{l}\text { II. METHODS } \\
\text { (3- job competency identification skill) } \\
\text { 4- cost-benefit analysis skill } \\
\text { 5- training objectives preparation skill } \\
\text { (6- professional experience evaluation } \\
\text { skill) } \\
\text { (7- learning organization and knowledge } \\
\text { management skill) }\end{array}$ & & $\begin{array}{l}X \\
X\end{array}$ & $\mathrm{X}$ & & \\
\hline $\begin{array}{l}\text { III. TECHNOLOGY } \\
\text { 8- computer and new information and } \\
\text { communication technologies } \\
\text { competence } \\
\text { 9- knowledge and education technologies } \\
\text { literacy }\end{array}$ & $X$ & $\mathrm{X}$ & $\mathrm{X}$ & $X$ & $X$ \\
\hline $\begin{array}{l}\text { IV. COMMUNICATION-ANIMATION } \\
\text { 10- feedback skill } \\
\text { 11- group process and teamwork skill } \\
\text { 12- negotiation skill } \\
\text { 13- verbal presentation skill } \\
\text { 14- questioning skill } \\
\text { 15- interpersonal relationship versatility }\end{array}$ & $\begin{array}{l}X \\
X \\
X \\
X \\
X \\
X\end{array}$ & $\begin{array}{l}X \\
X \\
X \\
X \\
X\end{array}$ & $\begin{array}{l}X \\
X \\
X \\
X \\
X \\
X\end{array}$ & $\begin{array}{l}X \\
X \\
X \\
X \\
X\end{array}$ & $\begin{array}{l}X \\
X \\
X \\
X \\
X \\
X\end{array}$ \\
\hline $\begin{array}{l}\text { V. STRATEGY } \\
\text { 16- prediction skill } \\
\text { 17- organization dynamics, structure and } \\
\text { strategy understanding }\end{array}$ & $\begin{array}{l}X \\
X\end{array}$ & & & & \\
\hline $\begin{array}{l}\text { VI. THEORY } \\
\text { 18- adult learning understanding } \\
\text { 19- library skills } \\
\text { 20- performance observation skill } \\
\text { 21- information and data base management } \\
\text { skill }\end{array}$ & $X$ & $\begin{array}{l}X \\
X \\
X\end{array}$ & $\begin{array}{l}X \\
X \\
X\end{array}$ & $\begin{array}{l}X \\
X \\
X\end{array}$ & $X$ \\
\hline $\begin{array}{l}\text { VII. PSYCHO-PEDAGOGY } \\
\text { 22- multimedia teaching skill } \\
\text { 23- counselling skill } \\
\text { 24- model building skill } \\
\text { 25- training and development techniques } \\
\quad \text { understanding } \\
\text { 26- learning sequence design skill } \\
\text { 27- individualizing instruction and } \\
\quad \text { learning skill } \\
\text { 28- tutoring and monitoring skill }\end{array}$ & $\mathrm{X}$ & $\begin{array}{l}X \\
X \\
X \\
X\end{array}$ & $\begin{array}{l}\mathrm{X} \\
\mathrm{X} \\
\mathrm{X} \\
\mathrm{X} \\
\mathrm{X} \\
\mathrm{X} \\
\mathrm{X}\end{array}$ & $\mathrm{X}$ & $X$ \\
\hline
\end{tabular}


The frame of reference was validated by surveying the situation in each participating institution. These results were consolidated in action training. This not only provided common descriptors, but also collective validation of the methodological tool.

\section{Field study}

The frame of reference resulting from this first stage consists of 14 roles (Table 2) and 28 competencies (Table 3) grouped into 7 categories: administration and organization, methods, technology, animationcommunication, strategy, theory, psycho-pedagogy.

The frame of reference has been used in the action research study carried out in the form of a field study in the participating institutions. The study first identified positions existing in each institution, the major roles associated with each position (in terms of the 14 roles of the frame of reference) as well as the associated key competencies (in terms of the 28 competencies of the frame of the reference). The participants then supplied an qualitative assessment, on a scale of 1 to 5 , of the impact of new information and communication technologies on the 28 competencies on each of the positions in each institution.

\section{Methodological limits}

There are several limits regarding the validity of the results:

- the sample of institutions cannot be considered as representative;

- the involvement of the participants introduces several biases specific to all action research studies;

- likewise, there are institutional biases in the observation of changes;

- the results must also be weighted by the very nature of the modification of competencies.

The results presented below should therefore be considered on a qualitative and indicative level, though they are pertinent to the aim sought, i.e. updating trainthe-trainer activities.

\section{MAIN RESULTS}

\section{Roles}

Four new jobs were identified with clearly defined outlines.

Head of Resource Centre: the resource centre is a training organization servicing individualization of training, selflearning and autonomous learning where the learner works alone or in a small group in selflearning mode with all 
types of adapted learning resources and the assistance of a trainer or tutor. The Head of the resource centre ensures the centre's administrative and educational management. This job was found in nearly all the institutions.

Head of Multimedia Open Learning: a trainer specialized in the design and administration of multimedia training courses. This job is becoming increasingly frequent in training organizations for setting up open and individualized training courses which use multimedia resources. This job is mostly administrative.

Tutor: this position exists when individualized training is given in a resource centre, whether this centre is located in a company or in a training organization. The role of the tutor is to help each individual to learn according to his or her particular curriculum and available learning resources, especially multimedia resources. The position of tutor does not exist when there is a Head of Multimedia Open Learning. This is logical since this person is often also responsible for multimedia training.

Animator or monitor: in the French framework of open multimedia learning this person mainly coaches the selflearning process. He or she is a specialist in multimedia learning resources, above all playing a role in logistics and in managing each learner's curriculum and training plan. This position is very different from that of a tutor. This does not coincide the case of the AngloSaxon framework of open learning where the role of a tutor is wider [4].

The trainer: the traditional role of the trainer does not disappear but, on the contrary, remains predominant while undergoing considerable change.

The main functions or roles outlined in our action research (Table 2) for each of the five positions are important for establishing new trainers' competencies. Two new roles are common to all the positions: multimedia specialist and individualized curriculum designer (with the exception of the animator/monitor). Next to the four managerial roles common to the Head Resource Centre and Head of Multimedia Open Learning (Table 2, roles 11 to 14) the new role of training system designer appears, a role of engineering media and technology based training systems.

\section{Key competencies}

Assessment of key competencies for each of the five positions (from the list of twenty-eight competencies) results in a key competency chart comprising seven axes arranged in a star [5]. The technology dimension constitutes a category of new key skills common to all the positions. This has direct 
consequences concerning training needs and professional development (Table $3)$.

Among the traditional competencies relevant to the theory dimension, there is now a new key skill known as information and data base management (Table 3 , skill 21).

Likewise, among the competencies relevant to the traditional area of psycho-pedagogy, the tutoring and monitoring skill (Table 3, skill 28) has now become a key competency common to the five positions (with the exception of Head Resource Centre which is a mainly management position).

Concerning the traditional competencies of communication-animation common to all the positions it is useful to know which of them are affected by the new information and communication technologies and constitute the new key competencies to be acquired.

\section{IMPACT OF INFORMATION TECHNOLOGY ON COMPETENCIES}

We have high lighted the key competencies affected by the new information and communication technologies (NICT), as well as some totally new competencies. Together these constitute a guideline for updating train-thetrainer activities. There are some new key competencies which, in a general way, concern all possible training positions (table 4):

- technology skills, as much basic computer and NICT technical skills as new cognitive skills in educational and knowledge technology in general;

- information and data base management skills (cognitive skills);

- two psycho-pedagogical skills: knowing how to select the multimedia tools and materials for training; and acquiring new competencies in tutoring and monitoring within the context of selflearning using NICT resources.

In addition, traditional competencies are affected by NICT and are therefore changed in nature or content. Some concern all training positions and others are more particularly concerned with the position of trainer (Table 4). These are the communication-animation skills which generally affect whatever position under consideration: feedback, group process and teamwork, negotiation skills and interpersonal relationship versatility. 
Table 4

\begin{tabular}{|c|c|c|c|c|c|}
\hline Impact of NICT on competencies & $\begin{array}{c}\text { Head } \\
\text { Resource } \\
\text { Centre }\end{array}$ & $\begin{array}{c}\text { Head } \\
\text { Multimedia } \\
\text { Open } \\
\text { Learning } \\
\end{array}$ & Trainer & Tutor & $\begin{array}{l}\text { Animator } \\
\text { or } \\
\text { Monitor }\end{array}$ \\
\hline $\begin{array}{l}\text { I. ORGANIZATION and ADMINISTRATION } \\
\text { 2- facilities and logistics skill }\end{array}$ & $X$ & & & & $X$ \\
\hline $\begin{array}{l}\text { II. METHODS } \\
\text { 4- cost-benefit analysis skill } \\
\text { 5- training objectives preparation skill }\end{array}$ & & $\mathrm{X}$ & $\mathrm{X}$ & & \\
\hline $\begin{array}{l}\text { III. TECHNOLOGY } \\
\text { 8- computer and new information and communication } \\
\text { technologies competence } \\
\text { 9- knowledge and education technologies literacy }\end{array}$ & $\begin{array}{l}X \\
X\end{array}$ & $\begin{array}{l}X \\
X\end{array}$ & $\begin{array}{l}X \\
X\end{array}$ & & $X$ \\
\hline $\begin{array}{l}\text { IV. COMMUNICATION-ANIMATION } \\
\text { 10- feedback skill } \\
\text { 11- group process and teamwork skill } \\
\text { 12- negotiation skill } \\
\text { 14- questioning skill } \\
\text { 15- interpersonal relationship versatility }\end{array}$ & $\begin{array}{l}X \\
X \\
X \\
X\end{array}$ & & $\begin{array}{l}X \\
X \\
X \\
X \\
X\end{array}$ & $\mathrm{X}$ & $\begin{array}{l}X \\
X \\
X\end{array}$ \\
\hline $\begin{array}{l}\text { V. STRATEGY } \\
\text { 16- prediction skill } \\
\text { 17- organization dynamics, structure and strategy } \\
\text { understanding } \\
\end{array}$ & $\begin{array}{l}X \\
X\end{array}$ & & & & \\
\hline $\begin{array}{l}\text { VI. THEORY } \\
\text { 18- adult learning understanding } \\
\text { 19- library skills } \\
\text { 20- performance observation skill } \\
\text { 21- information and data base management skill }\end{array}$ & $\mathrm{X}$ & $X$ & $\begin{array}{l}X \\
X \\
X\end{array}$ & $\mathrm{X}$ & $X$ \\
\hline $\begin{array}{l}\text { VII. PSYCHO-PEDAGOGY } \\
\text { 22- multimedia teaching skill } \\
\text { 23- counselling skill } \\
\text { 24- model building skill } \\
\text { 25- training and development techniques } \\
\quad \text { understanding } \\
\text { 26- learning sequence design skill } \\
\text { 27- individualizing instruction and learning skill } \\
\text { 28- tutoring and monitoring skill }\end{array}$ & $\mathrm{X}$ & $\mathrm{X}$ & $\begin{array}{l}X \\
X \\
X \\
X \\
\\
X \\
X \\
X\end{array}$ & $\begin{array}{l}X \\
X\end{array}$ & $X$ \\
\hline
\end{tabular}

As far as the trainer himself is concerned all the psycho-pedagogical skills are affected as well as all skills relevant to the theoretical domain; this demonstrates the changes in this position. Finally, new skills only concerning the position of the Head Resource Centre: organization, logistics and strategy skills.

\section{CONCLUSION : WHAT ARE THE RESULTS?}

Firstly, use of new information and communication technologies and setting up of multimedia training systems have changed the training function. Four new job categories have appeared and are today well established: Head Resource Centre Head, Head of Multimedia Open Learning, tutor and animator/monitor. 
Secondly, new key competencies are emerging which affect the whole range of training positions and have direct implications for train-the-trainer activities [6]: acquisition of computer and NICT competence, cognitive skills in the domain of information, data base management and knowledge technologies, psycho-pedagogical cognitive and attitude skills. Also several traditional competencies are affected and changed: communication-animation skills should be updated in the whole range of training positions. The trainer himself should update all cognitive skills related to learning theory and the subject of psychopedagogy particularly concerning the individualization of learning. The Head Resource Centre needs to acquire new competencies in organization, logistics and strategy.

Thirdly, there is a change in the content and nature of the job of the trainer himself. Almost all key competencies are affected and the whole range of cognitive, information, attitude and motor skills have to be upgraded. These new competencies of the trainer are directly related to multimedia training systems which are learner centred, shifting from teaching to learning, from teacher instruction to media based learning material, and from course delivery to individualized curriculum and selflearning. The new competencies are a direct effect of the paradigm shift from 'focusing on the teacher and teaching' to 'liberating the learner'.

The traditional training profession [7] has been transformed - a change in nature and an evolution towards professionalization of two major roles: training engineering (methods, tools and organization) and reinforcement and support of individual learning (tutoring, monitoring, interpersonal relationship).

The detailed specifications for the new competencies [8] will require further research in a longitudinal study. Already some short term work has been undertaken: an inventory of existing train-the-trainer resources has been created with respect to the new competencies and skills. Also the design of a hypermedia tool has been outlined which includes links between the trainer's profile, a database of training resources and constraints [9]. Finally, within this context, the organization of an internal ARDEMI users network has been set up-this network is interested in associating with other such networks on an international level.

\section{ACKNOWLEDGEMENT}

The authors thank Catherine Naville for conducting the field study based on grids and interviews derived from the new frame of reference. 


\section{REFERENCES}

1. Kugemann, W. F., (1994) The competent learner. Applied Learning Technologies in Europe, ALT, 6 (94E).

2. AFPA, (1993) Référentiel formation de formateurs. Direction de la Formation (internal report). Paris.

3. Craig, R. L. (1987) Training and Development Handbook. McGraw-Hill, New York.

4. Blandin, B. (1990) Formateurs et formation multimédia. les Editions Organisation.

5. Chretien-Petiot, C. (1994) Centres de ressources. ARDEMI internal report.

6. AFPA (1991) AFPA and the training of trainers current organisation and practice. Direction de la formation, Paris.

7. Caspar, P. and Vonderscher, M. J. (1986) Profession: responsable de formation. les Editions d'Organisation, Paris.

8. Gagné, R. M. and Briggs, L. J. (1979) Principles of Instructional Design. New-York Holt, Rinehart and Winston, (2nd edition).

9. The Training Technology Monitor (1994). Competencies to Use New Technologies in Training. 1 (6) p. 6. 